\title{
Environmental and social impact of a mini-hydropower plant based on Sudu Ganga in Sri Lanka
}

\author{
H.M.K.A. Herath ${ }^{1}$, R.A.R. Prabodanie ${ }^{* 1}$ and M.T.M.T. Wijewicrama ${ }^{2}$ \\ ${ }^{I}$ Department of Industrial Management, Faculty of Applied Sciences, Wayamba University of Sri Lanka, \\ Kuliyapitiya 60200, Sri Lanka. \\ ${ }^{2}$ Postgraduate Institute of Science. University of Peradeniya, Peradeniya, Sri Lanka. \\ *Correspondence: ranga@wyb.ac.lk; (D) ORCID: https://orcid.org/0000-0001-8113-8682
}

Received: 09 ${ }^{\text {th }}$ September 2020, Revised: $18^{\text {th }}$ June 2021, Accepted: 30 June 2021

\begin{abstract}
Hydropower plants are generally considered as economical and sustainable sources of energy, yet they can create unintended disruptions to sensitive ecosystems. The objective of this study was to assess the environmental and social impact of a proposed mini-hydropower plant based on Sudu Ganga (Matale district) in Sri Lanka. Data for the environmental impact assessment were obtained via species observation and from secondary sources. Data for social impact assessment were obtained through the views of the residents and other stakeholders in the area. The regulation degree was $0.052 \%$ which indicated minor impact on the hydrological flow regime. In the project area, the study identified 28 flora species and 30 fauna species including five flora and fauna species at high risk of disappearance, and another five species at the risk of falling into a threatened category. The estimated value of the Shannon biodiversity index for flora species was 1.71 and was lower compared to other ecologically sensitive areas in surrounding districts. The environmental impact values for the physical and biological environment, and the social environment were -0.65 and 1.4 , respectively, on a scale of $[-5,5]$. These values indicate a slight negative impact on the physical and biological environment but a positive impact on the social environment. The proposed reforestation project and fish bypass gate were recognized as significant mitigation measures. We recommend further precautionary measures, particularly, during the construction phase to minimize disturbance to wildlife and damages to plant species, proper management of site excavation and construction waste, careful use of machinery and vehicles, environmental awareness of employees, and involvement of community and stakeholders to reduce adverse impacts.
\end{abstract}

Keywords: Environmental assessment, hydropower, impact mitigation, Mahaweli project, Shannon-biodiversity index

\section{Introduction}

Hydropower plants are usually considered as economically viable investments (Gyamfi et al. 2018, Ummalla and Samal 2018). Since these do not burn fuel for 
electricity generation, the operating cost is low, and hydropower is virtually immune to fuel price fluctuations. In 2017, major hydropower plants contributed $20.5 \%$ of the total gross electricity generation in Sri Lanka and mini-hydropower plants contributed another 6.34\% (SLSEA 2017). In the same year, the average unit cost of hydropower was Rs. 2.77 per $\mathrm{kWh}$ when the unit costs of coal and fuel oil-based power generation stood at Rs. 9.74 and 25.75, respectively (SLSEA 2017). Recent studies on mini-hydro development in Sri Lanka have identified that the current gridconnected mini-hydro capacity of $393.5 \mathrm{MW}$ can be increased up to 873MW (CEB 2019).

Economic viability is not the only attractiveness of hydropower plants. Hydropower generation is a non-consumptive use of water and a sustainable and renewable source of energy which has lesser impact on the environment compared to coal and fuel-based power generation. It provides other widely recognized benefits including infrastructure development, irrigation, and employment.

Despite the economic benefits, hydro facilities can have unintended environmental and social impacts (World Commission on Dams 2000, Edenhofer 2011, Kibler and Tullos 2013, De Faria et al. 2017). Those may interfere with the natural flow of water and disturb the ecological connectivity in the catchments. Construction of weirs and water storage can affect reproduction and migration of riparian and aquatic species, and cause habitat losses and extinction or reduction in species/ populations (World Commission on Dams 2000, Kibler and Tullos 2013, Mendis 2019). Large scale construction on upstream land using heavy machinery generates excessive noise and emissions which can pose threats to wildlife, and can de-stabilize the hill slopes increasing the risk of landslides. Hydro facilities can increase sedimentation and degrade water quality. In addition, hydropower plants can have social impacts such as residential and agricultural relocation, changes in livelihood, and lifestyle changes induced by associated developments (Gunatillake and Thiruchelvam 2003, Thoradeniya et al. 2007). Long term social impacts of hydropower plants have sometimes been questioned in the context of developing countries (De Faria et al. 2017). Recent research has found that the impacts of small hydropower plants can be even worse compared to those of large hydropower plants particularly with respect to habitat and hydrology (Kibler and Tullos 2013).

Owing to the above reasons, the planning stage of hydropower plants should include independent and comprehensive assessment of environmental and social impacts (World Commission on Dams 2000). The impact assessment studies must identify and delineate geographical areas, people and ecological populations affected and evaluate the potential impacts considering environmental, social and demographic standards. Such assessments enable the project decision makers to derive mitigation, resettlement and development plans in a more proactive and less costly manner (World Commission on Dams 2000).

Currently, there are 194 active mini-hydropower plants in Sri Lanka (CEB 2019) where both positive and negative impacts have been observed, but socioeconomic benefits dominate. Most of those plants are located in upstream catchment areas in 
the hill country which consists of sensitive ecosystems. While environmental lobbies argue that mini-hydro facilities can disturb those ecosystems and traditional water users downstream (Rupasinghe and de Silva 2007, Mendis 2019), developments accompanied by mini-hydropower plants in such rural areas have had favourable socioeconomic impacts appreciated by the communities (Gunatillake and Thiruchelvam 2003, Thoradeniya et al. 2007, Wijenayake 2016).

Recently, the proposed Kithulgala mini-hydropower project has come under huge criticism after environmental studies have found rare and endangered species in the area (Mendis 2019). The studies have identified 39 fish species including 22 endemic species residing in the area. Out of the 22 endemic species, 17 have been identified as under threat of extinction. A critically endangered species known as 'Asoka Pethiya' (Systomus asoka) is restricted to a few locations in Kelani and Seethawaka basins and an endemic species confined to Kithulgala area has also been identified. However, some have argued that the benefits of low-cost electricity and rural infrastructure development are enormous, and the unavoidable alteration to the environment is negligible compared to the benefits of mini-hydropower plants (Gunatillake and Thiruchelvam 2003, Wijenayake 2016). An analysis shows that out of 34 active minihydropower plants in Sri Lanka, only two have used forest land while most have used state and private properties (Wijenayake 2016). Gunatillake and Thiruchelvam (2003) who studied the economic viability of a proposed mini-hydropower plant based on Maskelioya, a tributary of Kalu Ganga found that the cost of deforestation, flow reduction and other environmental losses are surpassed by socioeconomic benefits such as electricity, employment and infrastructure development. Thoradeniya et al. (2007) found that employment opportunities created by the minihydropower plants in the Uma-Oya basin and the accompanied development of rural infrastructure, particularly the access road which subsequently appreciated the land value were the significant benefits welcomed by the community.

The objective of this study was to identify the potential environmental and social impacts of the proposed mini-hydropower plant based on Sudu Ganga (Matale district), Sri Lanka where several other previously installed mini-hydropower plants are present, and to report the outcomes of an environmental and social impact assessment. The outcomes of this work would help the planners to identify potential adverse impacts, to incorporate mitigation measures into the proposal, and to get stakeholder support and government approval. The outcomes will also serve as a guideline to identify potential impacts of other mini-hydropower plants as well as any specific species or populations to be considered in future.

\section{Material and Methods}

\subsection{Study site}

This study focused on a proposed mini-hydropower plant based on Sudu Ganga, Matale, Sri Lanka which is a water body connected to the greater Mahaweli project. 
Mahaweli waters diverted from Polgolla via Polgolla-Ukuwela tunnel is discharged into Sudu Ganga after generating electricity at Ukuwela power plant (CEB 2019). As at the time of this study, there were eight active mini-hydropower plants along Sudu Ganga, namely Dun Oya, Kiula, Brand Ford, Owala, Ross state, Diggala, Ankanda and Rajjammana (Figure 1). Along $21 \mathrm{~km}$ of Sudu Ganga from Kiula village at 342 $\mathrm{m}$ altitude to Rajjammana village at $276 \mathrm{~m}$ altitude, there are seven active minihydropower plants (Silva and Silva 2016), and the proposal is to construct a new plant with a capacity of $6 \mathrm{MW}$. The catchment area is $316 \mathrm{~km}^{2}$. The proposed hydropower plant is a "run-of-river" type hydropower facility which does not hold the water in a reservoir (World Commission of Dams 2000).

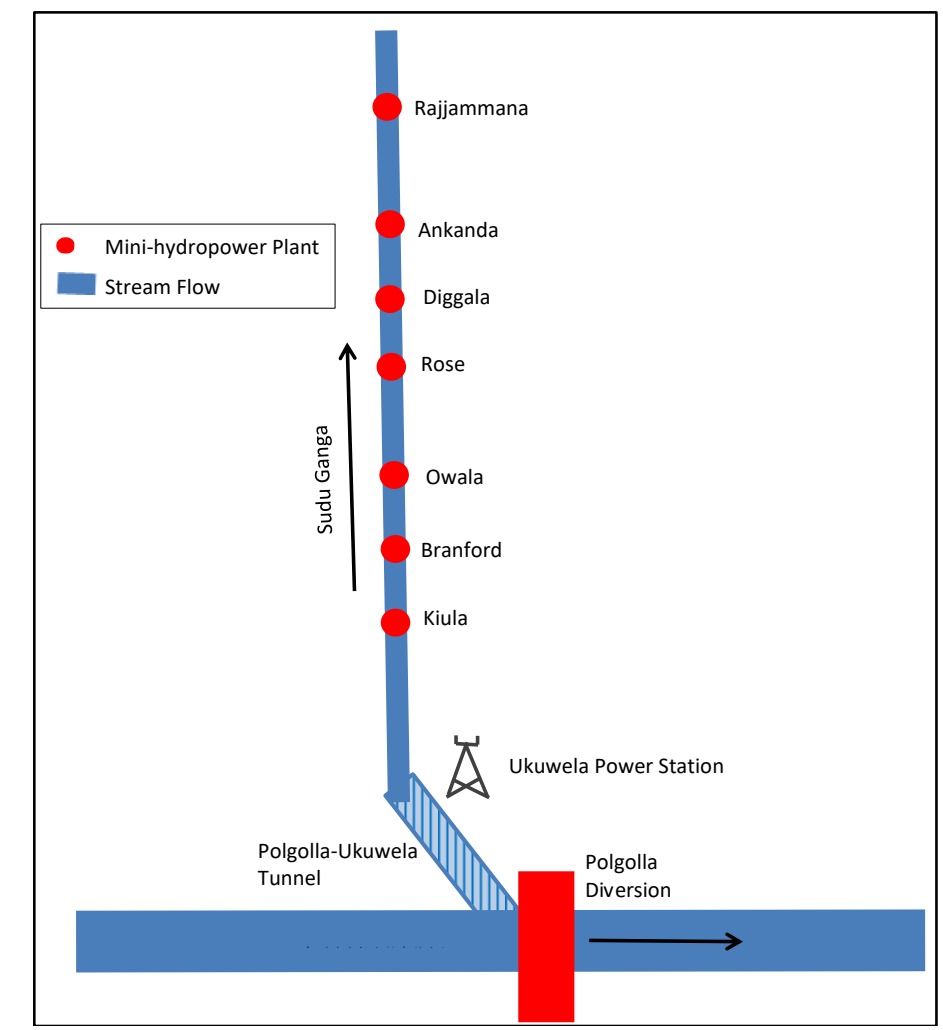

Fig 1. Mini-hydropower plants based on Sudu Ganga. This schematic diagram was adapted from Silva and Silva (2016).

\subsection{Environmental and social impact assessment}

The data used for the environmental impact assessment was from secondary sources such as hydrological reports and project plans obtained from the investor of the 
proposed project, the engineering drawings of the proposed project, and from field observations carried out to identify flora and fauna species which could be affected by the project. The data for the social impact assessment were obtained from villagers of the surrounding area (who are in the impact circle), investors of the project, and other stakeholders. The residents in the area who responded to the survey were somewhat aware of the impacts of the other hydropower plants located in the region.

To study the environmental and social impact of the proposed hydro facility, we used three widely used measures, namely, Regulation Degree, Environmental Impact Value and Shannon Biodiversity Index.

\section{Regulation Degree}

The primary impact of a hydropower plant on a freshwater ecosystem is the alteration of natural flow. Regulation Degree (RD) is a widely used measure to quantify the effect on natural flow whereas a higher estimate of RD indicates a severe impact on the natural flow regime. A value less than 10 is considered good, and a value greater than 50 is considered poor (Steinmetz and Sundqvist 2014, Eriyagama et al. 2020).

$$
\text { Regulation Degree }(\%)=\frac{\text { Total water Volume that can be stored }}{\text { Annual flow volume }} \times 100 \%
$$

Since the proposed hydropower plant is run-of-river type which does not have water storage in a reservoir, the alteration of flow is expected to be a minimum. However, since there is a weir to divert the water and it creates a pool, the RD was calculated. To calculate the RD, 23 years of historical river flow data at some points of Sudu Ganga were obtained from the hydrological reports owned by the investor of the proposed project. The architectural plans of the proposed site were also used to obtain the data.

Table 1: Monthly average maximum and minimum flows $\left(\mathrm{m}^{3} / \mathrm{s}\right)$ at the proposed project location.

\begin{tabular}{lcc}
\hline Month & Maximum flow & Minimum flow \\
\hline January & 55.77 & 12.18 \\
February & 46.90 & 8.88 \\
March & 7.80 & 4.60 \\
April & 7.89 & 3.64 \\
May & 11.61 & 3.80 \\
June & 15.97 & 3.15 \\
July & 19.90 & 5.34 \\
August & 19.69 & 7.69 \\
September & 14.58 & 3.98 \\
October & 26.80 & 13.78 \\
November & 20.71 & 19.84 \\
December & 41.14 & 14.67 \\
Average & 24.06 & 8.46 \\
\hline
\end{tabular}


Considering cascading down of flow along the river, possible evaporation and infiltration losses, and tributary inflows, monthly maximum and minimum stream flows at the proposed site location were estimated as given in Table 1. According to the monthly flow data, the average stream flow at the proposed project location over all months is $16.26 \mathrm{~m}^{3} / \mathrm{s}$. Assured flow from Polgolla diversion is 875 million cubic meters annually $\left(27.75 \mathrm{~m}^{3} / \mathrm{s}\right.$ ) (De Silva and Hornberger 2019). After a $10 \%$ flattening of the diverted flow, we estimated the total annual flow at the project location as $\left(16.26 \mathrm{~m}^{3} / \mathrm{s}+(27.75 \times 0.90) \mathrm{m}^{3} / \mathrm{s}\right) \times(365 \times 24 \times 3600)=1,300,386,960 \mathrm{~m}^{3}$ to calculate the regulation degree.

\section{Environmental Impact Value (EIV)}

The EIV is a widely used measure of the aggregate environmental impact of a project. In this work, we considered the physical, biological and social environment from a qualitative perspective. The general formula for EIV (Safont et al. 2012) is given below as:

$$
E I V=\sum_{i=1}^{n} V_{i} \times W_{i}
$$

where $V_{i}$ corresponds to the relative change in the environmental quality parameter (criterion) $i, W_{i}$ is a weight factor which indicates the relative importance of parameter $i$ and $n$ is the number of parameters considered.

Based on previous studies (Kibler and Tullos 2013, Steinmetz and Sundqvist 2014, Zelenáková et al. 2018) and stakeholder opinions, we selected a set of environmental quality parameters which provide a qualitative assessment of the physical, biological and social environment of the study area. The selected physical and biological environmental parameters were climate and air quality, hydrology and flow regime, land use and topography, water quality, sedimentation, solid waste, noise and vibration, forest cover, flora species, flora diversity, fauna species, fish migration and downstream effect. The social parameters considered were agriculture, culture and religion, public health, lifestyle, employment, local trade, rural industry and transport.

Impacts on the environmental parameters were scaled as severe $(+5$ or -5$)$, higher $(+4$ or -4$)$, moderate $(+3$ or -3$)$, low $(+2$ or -2$)$, very low $(+1$ or -1$)$ or no change $(0)$ based on the information provided by the proponent of the project and expert opinion (in case of physical and biological environmental impact) and based on survey data (in case of social impact). A survey questionnaire was used to collect social impact data from a sample of 35 residents who were aware of hydropower developments in the area and two others from a Buddhist Temple and a Hindu Kovil located in the proposed project area.

The weight factors for physical and biological parameters were assigned based on those used in previous studies (Safont et al. 2012, Zelenáková et al. 2018), and the opinions of stakeholders including engineers, environmentalists, and some residents 
in the area. Initially, weights of 2,1 and 0 were assigned to very significant, significant and insignificant parameters respectively, and then they were normalized to obtain fractional weights indicating relative importance. The weight factor for each social impact factor was calculated from the responses of survey participants to a question on which factors were most important to them. Weights were assigned proportionally to the number of respondents who identified each factor as important. Normalized weights were used in calculating EIV.

\section{Species identification}

Owing to the ecological sensitivity of Sudu Ganga and surrounding catchment area, the identification of flora and fauna species that could be affected by the proposed mini-hydropower plant was an important aspect of this study. The species identification was done in two stages, photographic imaging and identification. In the first stage, some field visits to the project location were arranged from January to March 2020 and photographs of species were taken with the help of a specialist in nature studies.

In the flora identification process, photographs of the plants from different angles and photographs of the leaves were taken. The total number of trees was counted manually and the number of occurrences of herbs and ferns per unit square area ware recorded as the counts were required for calculating the Shannon Biodiversity Index for flora species. For fauna species identification also, photography sessions were carried out. The photographed species identification was done with the help of a specialist using the National Red List 2012 (MOE 2012) and other published data (Mahaweli Consultancy Bureau 2014).

\section{Shannon Biodiversity Index}

Shannon Index of Biodiversity is a widely used measure of species diversity within a community (Iglesias-Rios and Mazzoni 2014, Suratissa and Rathnayake 2016). Since Shannon index is based on the relative abundance of different species, it indicates community composition. The formula for Shannon Biodiversity Index $H$ (IglesiasRios and Mazzoni 2014) is:

$$
H=-\sum_{i=1}^{n} p_{i}\left[\ln \left(p_{i}\right)\right]
$$

where, $p_{i}$ is the proportion of the observations of species $i$ relative to the total number of observations of species in the community (area) and $n$ is the number of individual species types in the community. The quadrat sampling method was used to estimate the counts of small herbs and ferns. In this method, the number of observations in a unit square area is multiplied by the area of the entire population to estimate the number of occurrences in the concerned area. We used $0.5 \mathrm{~m}^{2}$ quadrats for sampling. Some other large flora species were counted manually. 
Both species counts and number of occurrences in the area are required to calculate the Shannon biodiversity index. Owing to the difficulties in estimating the counts of fauna species, we calculated the index for plant diversity only.

\section{Results}

\subsection{Regulation Degree}

Using the dimensions of the cross-sectional plan of the proposed weir and backwater curve study estimates, the storage volume of the pool created by the weir was estimated as $673,304.493 \mathrm{~m}^{3}$. Hence the Regulation Degree (\%) was calculated as $(673,304.493 / 1,300,386,960) \times 100=0.052 \%$.

\subsection{Species Identification}

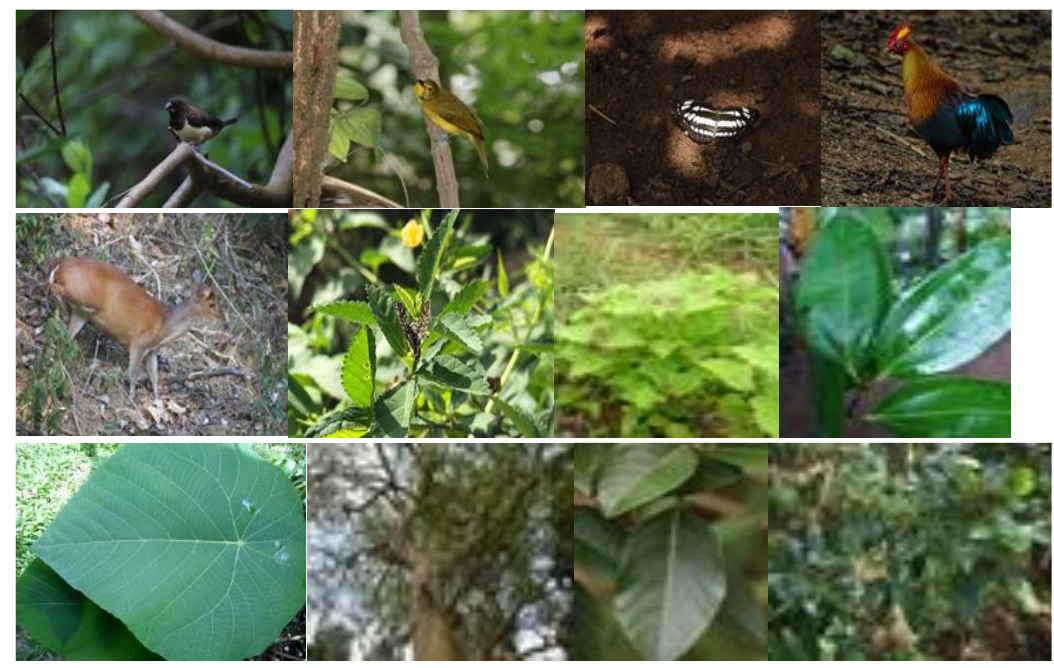

Fig 2. Some flora and fauna species found in the neighborhood of Sudu Ganga.

Species identified (Figure 2) through site visits, photographic images, expert help, and reference to the national red list are listed in Tables 2 and Table 3. In the species identification process, 28 flora species were identified including 19 native species and 9 exotic species. The flora and fauna species identified in this study were categorized based on their national conservation status as specified in the red list (Table $2 \& 3$ ). There were 3 red listed flora species out of which two were classified as vulnerable (VU) and one was classified as near threatened (NT). Others were the least concerned (LC) species. The list of identified fauna species (Table 3) consisted of 30 species including three vulnerable species and four near threatened species. 
However, the identification of fauna species may not be fully inclusive owing to the limited number of visits and timeframe of the study.

Table 2: Flora species identified in the Sudu Ganga mini-hydropower project area. Conservation status is as specified in the National Red List 2012 (VU=vulnerable, NT=near threatened, $\mathrm{LC}=$ least concerned, $\mathrm{NL}=$ not listed).

\begin{tabular}{lllll}
\hline Family & Species & Origin & Life Form & Status \\
\hline Fabaceae & Saraca asoca & Native & Tree & VU \\
Phyllanthaceae & Margaritaria indica & Native & Tree & VU \\
Cornaceae & Alangium salviifolium & Native & Climber & NT \\
Cannabaceae & Trema orientalis & Native & Tree & LC \\
Combretaceae & Terminalia arjuna & Native & Tree & LC \\
Dilleniaceae & Dillenia indica & Native & Tree & LC \\
Fabaceae & Pongamia pinnata & Native & Tree & LC \\
Lauraceae & Cinnamomum cassia & Native & Tree & LC \\
Meliaceae & Walsura trifoliolata & Native & Tree & LC \\
Moraceae & Streblus taxoides & Native & Tree & LC \\
Rhizophoraceae & Cassipourea ceylanica & Native & Shrub & LC \\
Sapindaceae & Cardiospermum halicacabum & Native & Climber & LC \\
Combretaceae & Terminalia catappa & Native & Tree & LC \\
Annonaceae & Polyalthia korinti & Native & Shrub & LC \\
Cannabaceae & Celtis philippensis & Native & Tree & LC \\
Euphorbiaceae & Macaranga peltata & Native & Tree & LC \\
Pteridaceae & Adiantum caudatum & Native & Fern & LC \\
Asteraceae & Eleutheranthera ruderalis & Exotic & Herb & NL \\
Meliaceae & Swietenia macrophylla & Exotic & Tree & NL \\
Onagraceae & Ludwigia peruviana & Exotic & Shrub & NL \\
Lamiaceae & Tectona grandis & Native & Tree & NL \\
Piperaceae & Piper nigrum & Native & Climber & NL \\
Fabaceae & Leucaena leucocephala & Exotic & Tree & NL \\
Asteraceae & Chromolaena odorata & Exotic & Shrub & NL \\
Verbenaceae & Lantana camera & Exotic & Shrub & NL \\
Poaceae & Panicum maximum & Exotic & Herb & NL \\
Legumes & Gliricidia maculata & Exotic & Tree & NL \\
\hline
\end{tabular}

\subsection{Shannon Biodiversity Index}

Shannon Biodiversity index was calculated for flora diversity assessment only. The estimated (or observed) counts for five different types of flora species are given in Table 4. Considering all the 28 flora species and their counts, the estimated value of the Shannon index was 1.7105 .

Since some of the trees are to be cut down in the construction phase, we made a rough estimate of the Shannon index after the construction of the proposed plant, taking into account the remaining numbers of trees. Since ferns and herbs regrow quickly, we ignored any reduction in those counts. The number of trees to be removed due to the project is given in Table 4. The estimated index after construction was 1.6626 . 
Table 3: Fauna species identified in the Sudu Ganga mini-hydropower project area. Conservation Status is as specified in the National Red List 2012 (VU=vulnerable, NT=near threatened, LC=least concerned).

\begin{tabular}{llll}
\hline Family & Genus/ Species & Faunal group & Status \\
\hline Rhacophoridae & Pseudophilautus fergusonianus & Amphibian & VU \\
Nymphalidae & Idea iasonia Westwood & Butterfly & VU \\
Cyprinidae & Garra ceylonensis & Fish & VU \\
Belontidae & Belontia signata & Fish & NT \\
Cyprinidae & Tor khudree & Fish & NT \\
Cervidae & Muntiacus muntjak & Mammal (deer) & NT \\
Rhacophoridae & Pseudophilautus popularis & Reptile & NT \\
Cyprinidae & Puntius bimaculatus & Fish & LC \\
Channidae & Channa gachua & Fish & LC \\
Cyprinidae & Dawkinsia singhala & Fish & LC \\
Timaliidae & Pomatorhinus melanurus & Bird & LC \\
Phasianidae & Gallus lafayetii & Bird & LC \\
Agamidae & Calotus calotus & Reptile & LC \\
Dicroglossidae & Minervarya agricola & Reptile & LC \\
Varanidae & Varanus bengalensis & Amphibian & LC \\
Hesperiidae & Spialia galba Fabricius & Butterfly & LC \\
Estrildidae & Lonchura striata & Bird & LC \\
Accipitridae & Haliaeetus leucogaster & Bird & LC \\
Papilionidae & Papilio clytia Linnaeus & Butterfly & LC \\
Nymphalidae & Neptis hylas & Butterfly & LC \\
Libellulidae & Trithemis aurora & Dragonfly & LC \\
Libellulidae & Trithemis festiva & Dragonfly & LC \\
Pycnonotidae & Acritillas indica & Bird & LC \\
Agamidae & Calotes versicolor & Reptile & LC \\
Colubridae & Ahaetulla nasuta & Reptile & LC \\
Papilionidae & Troides darsius Gray & Butterfly & LC \\
Muscicapidae & Cyornis tickelliae & Bird & LC \\
Passeridae & Passer domesticus & Bird & LC \\
Muscicapidae & Muscicapa muttui & Bird & LC \\
Columbidae & Chalcophaps indica & Bird & \\
\hline & & & LC \\
\hline
\end{tabular}

Table 4: Counts of five flora species and numbers of trees to be cut down due to Sudu Ganga mini-hydropower plant.

\begin{tabular}{lllll}
\hline \multicolumn{2}{c}{ Existing numbers of fauna species } & & \multicolumn{2}{c}{ Number of trees to be cut } \\
\hline Species/ Family & Form & Count & Species & No. \\
\hline Trema orientalis & Tree & 3 & Trema orientalis & 2 \\
Ludwigia peruviana & Shrub & 4 & Tectona grandis & 1 \\
Cardiospermum halicacabum & Climber & 11 & Terminalia catappa & 8 \\
Eleutheranthera ruderalis & Herb & 376 & Lantana camera & 9 \\
Pteridaceae & Fern & 446 & & \\
\hline
\end{tabular}




\subsection{Environmental Impact Value (EIV)}

The EIV for the physical and biological environment and the EIV for the social environment were calculated separately as different methods were used for data collection. The data for impacts on physical and biological environmental parameters were acquired from the information provided by the investor of the proposed project and a specialist in the particular area. The data for the impacts on the social environment were collected through a survey questionnaire as described above. Based on the data summarized in Tables 5 and 6, the calculated EIVs for physical and biological impact and social impact were -0.65 and 1.4 respectively.

Table 5: Physical and biological environmental impacts of Sudu Ganga mini-hydropower plant, justifications and weights assigned.

\begin{tabular}{|c|c|c|c|}
\hline Parameter & $\begin{array}{l}\text { Impact } \\
{[-5,5]}\end{array}$ & Justification & $\begin{array}{l}\text { Weight } \\
{[0,1]}\end{array}$ \\
\hline $\begin{array}{l}\text { Climate and air } \\
\text { quality }\end{array}$ & 0 & $\begin{array}{l}\text { Few vehicles and machinery will be used during } \\
\text { construction. }\end{array}$ & 0.10 \\
\hline $\begin{array}{l}\text { Hydrology and } \\
\text { flow regime }\end{array}$ & -1 & $\begin{array}{l}\text { Regulation degree is close to zero. Run of river type hydro } \\
\text { plants do not usually alter the hydrology. }\end{array}$ & 0.10 \\
\hline $\begin{array}{l}\text { Land use and } \\
\text { topography }\end{array}$ & -1 & $\begin{array}{l}\text { The selected area is not cultivated. Excavated material will } \\
\text { be used for filling. }\end{array}$ & 0.10 \\
\hline Water quality & 0 & No waste or chemical disposal to the water. & 0.10 \\
\hline Sedimentation & 0 & $\begin{array}{l}\text { Run of river type hydro plants have negligible impact on } \\
\text { sedimentation. }\end{array}$ & 0.05 \\
\hline Solid waste & 0 & No solid waste generation. & 0.05 \\
\hline $\begin{array}{l}\text { Noise and } \\
\text { vibration }\end{array}$ & -3 & $\begin{array}{l}\text { Plant capacity is } 6 \mathrm{MW} \text {. Vibration and noise effect will be } \\
\text { considerable during power generation. }\end{array}$ & 0.05 \\
\hline Forest cover & 3 & $\begin{array}{l}\text { Project area is not considered as forest. The proposal } \\
\text { includes a reforestation project on the other side of the } \\
\text { river. }\end{array}$ & 0.10 \\
\hline Flora species & -1 & $\begin{array}{l}\text { Some trees will be cut for constructing the powerhouse. No } \\
\text { critically endangered or endangered species is affected. }\end{array}$ & 0.10 \\
\hline Flore diversity & -1 & $\begin{array}{l}\text { Reduction in the Shannon index for flora diversity is very } \\
\text { low. }\end{array}$ & 0.05 \\
\hline Fauna species & -1 & No critically endangered or endangered species is affected. & 0.10 \\
\hline Fish migration & -1 & $\begin{array}{l}\text { A fish bypass gate (fish ladder) is already added to the } \\
\text { project plan. }\end{array}$ & 0.05 \\
\hline $\begin{array}{l}\text { Downstream } \\
\text { effect }\end{array}$ & 0 & $\begin{array}{l}\text { All water will be discharged instantly after power } \\
\text { generation (when idle, through the spillways). River } \\
\text { water will not be used for site activities. }\end{array}$ & 0.05 \\
\hline
\end{tabular}


Table 6: Social impact (rounded averages of responses) Sudu Ganga minihydropower plant and weights assigned.

\begin{tabular}{lcc}
\hline Parameter & Impact $[-5,5]$ & Weight $[0,1]$ \\
\hline Agriculture & -1.0 & 0.10 \\
Culture and religion & -3.0 & 0.10 \\
Public health & -1.0 & 0.20 \\
Lifestyle & 0.0 & 0.05 \\
Employment & 4.0 & 0.10 \\
Local trade & 3.0 & 0.10 \\
Transport & 4.0 & 0.10 \\
Infrastructure & 4.0 & 0.15 \\
Rural Industry & 3.0 & 0.10 \\
\hline
\end{tabular}

\section{Discussion}

It is generally accepted that alteration of natural flow is the main impact of hydropower plants on aquatic ecosystems. For the proposed mini-hydropower plant, the estimated value of the regulation degree is $0.052 \%$ which is close to zero and can be ranked as very good. A lower value is always favourable for the hydrological flow regime and a value less than 10 is considered as good (Steinmetz and Sundqvist 2014, Eriyagama et al. 2020). Hence the proposed mini-hydropower plant has little impact on the natural flow regime of Sudu Ganga. A similar study on mini-hydro facilities in Sweden has estimated the regulation degree for a mini-hydropower plant with 5.3 MW capacity as $27 \%$ which was unsatisfactory and the same for another small hydropower plant with 1.79 MW capacity as $14.6 \%$ which was moderate (Steinmetz and Sundqvist 2014). Compared to those two cases, the regulation degree calculated for the proposed plant with a higher capacity of $6 \mathrm{MW}$ is significantly low.

Flora and fauna species in the project area were identified in order to assess whether the proposed project can have any adverse impact on endangered species. We identified 28 flora species out of which 3 were included in the red list and 30 fauna species out of which 7 were included in the red list. Out of the 28 flora species, 19 were native and others were exotic. The national red list has categorized the national conservation status of flora and fauna species as Extinct (EX), Extinct in the Wild (EW), critically endangered (CE), endangered (E), vulnerable (VU), near threatened (NT) and least concerned (LC) in order of the importance of conservation (MOE 2012). None of the critically endangered or endangered species was found in the area. However, there were few vulnerable and near threatened species. Specifically, there were two vulnerable native flora species and three vulnerable fauna species: a fish, a butterfly and an amphibian. Those species are at high risk of disappearance in Sri Lanka. There was one native climber-type fauna species, one reptile species, one animal species and two fish species which were in the near threatened category. These species are also at the risk of falling into the threatened status. Altogether, out of the 58 species identified, 10 were in the categories of 
vulnerable or near threatened. Since this number is not negligible, precautionary measures should be adopted particularly during the construction phase to minimize disturbance to wildlife and to minimize damages to plant species. The proposed fish bypass gate is a commendable feature of the proposed project, and it can be recommended as a good practice for minimizing the effects on threatened fish species.

The estimated value of the Shannon biodiversity index for flora species was 1.71054. The expected change in the index (from 1.71054 to 1.6626 ) is relatively low. A study has found that the plant diversity in the nearby Horton plains (about 80 $\mathrm{km}$ to the South of the project area) is 3.1 in the cloud forest and 1.71 in grasslands (DWC 2007). In Polonnaruwa sanctuary (about $75 \mathrm{~km}$ to the north of the project area), the Shannon index for pant diversity has been estimated as 4.23 decades ago (Dittus 1977) which may have declined now. Hence the plant diversity in the project area is lower or at least not greater compared to the ecologically sensitive areas in adjacent districts. Since a re-forestation scheme is already included in the project, the long-term impact on flora species is expected to be favourable.

The environmental impact value was calculated for the physical and biological environment using 13 parameters on which the impact was scaled between -5 and 5 and was weighted fractionally. The estimated environmental impact value (physical and biological) was -0.65 which is between 0 (no impact) and -1 (very low negative impact). Hence even if the impacts on individual parameters were slightly above the assigned levels, the overall impact would not be worse than a very low negative impact. However, the social impact calculated using a similar scale and weights was 1.4 which is between 1 (very low positive impact) and 2 (low positive impact). Hence there is at least some positive impact on the social environment. In particular, the villagers around the proposed project location were expecting employment opportunities and permission to cross the dam, which they considered as potential positive impacts of the project. By fulfilling these expectations, social acceptance and support for the proposed project can be enhanced. Our results generally agree with the previous studies which have observed that mini-hydropower plants have favourable socio-economic impacts such as employment opportunities and developed infrastructure, particularly for rural communities (Gunatillake and Thiruchelvam 2003, Thoradeniya et al. 2007, Wijenayake 2016).

Though mini-hydropower plants are widely criticized by the environmental community over habitat losses (Kibler and Tullos 2013, Mendis 2019), any type of development other than hydropower facilities can also cause the same or even more disturbance to ecological habitats. Decades of experience have shown that most minihydro developers are aware of the environmental impacts and have introduced mitigation and control measures (Wijenayake 2016). The reforestation project proposed by the project investors is one such initiative which can overturn the negative environmental impacts. In addition, proper management of site excavation and construction waste, careful use of machinery and vehicles, environmental 
awareness of employees and involvement of community and stakeholders would further help in reducing any adverse impacts of the proposed mini-hydropower plant.

\section{Conclusions}

The results indicate a slight negative impact on the physical and biological environment and a positive impact on the social environment. The expected negative impacts of the proposed mini-hydropower plant are low compared to the social and economic benefits of low-cost hydropower.

The contributions of this work extend well beyond the assessment of the environmental and social impact of one proposed mini-hydropower plant, as several other small scale hydropower plants are to be established in future. Our results provide an understanding of the flora and fauna species in the surrounding ecosystem as well as the community concerns in hydropower development.

The estimated values of the impacts are only indicative values as the scores and weights used can be subjective, particularly in the context of the physical and biological environment. The list of both flora and fauna identified may not be exhaustive as the study was limited to the site area and to a limited time frame, there may be seasonal migrants which were not identified in the study. We used only a few measures to evaluate the environmental impacts while there are several other measures which could have generated a better understanding of the hydrological and ecological impacts (Eriyagama et al. 2020). The broader long-term effects should be studied at the river basin scale taking into account the number, distribution, sizes and locations of the hydropower plants within the basin. Since there are other hydropower plants along Sudu Ganga, an overall assessment of the collective impacts of all hydropower plants would be extremely useful.

\section{Acknowledgements}

Authors acknowledge the valuable inputs of the project investor, the residents in the study area, the environmentalists, and other stakeholders. Two anonymous reviewers are acknowledged for critical comments on the initial manuscript.

\section{References}

CEB. 2019. Long term generation expansion plan 2020-2039. Ceylon Electricity Board, Colombo.

De Faria FAM, Davis A, Severnini E, Jaramillo P. 2017. The local socio-economic impacts of large hydropower plant development in a developing country. Energy Economics 67: 533-544.

De Silva MT, Hornberger GM. 2019. Assessing water management alternatives in a multipurpose reservoir cascade system in Sri Lanka. Journal of Hydrology: Regional Studies 25:100624.

Dittus WPJ. 1977. The ecology of a semi-evergreen forest community in Sri Lanka. Biotropica 9(4): 268-286. 
DWC. 2007. Biodiversity baseline survey: Horton Plains National Park. Consultancy Services. Report prepared by Green MJB (ed.), De Alwis SMDAU, Dayawansa PN, How R, Singhakumara BMP, Weerakoon D, Wijesinghe MR. ARD Inc in association with Infotech IDEAS and GREENTECH Consultants. Department of Wildlife Conservation, Ministry of Environment and Natural Resources, Colombo.

Edenhofer OPM. 2011. Renewable energy sources and climate change mitigation: Special report of the intergovernmental panel on climate change. Cambridge University Press, Cambridge.

Eriyagama N, Smakhtin V, Udamulla L. 2020. How much artificial surface storage is acceptable in a river basin and where should it be located: a review. Earth-Science Reviews 208: 103294.

Gyamfi S, Derkyi NSA, Asuamah EY. 2018. Chapter 7 - The potential and the economics of hydropower investment in West Africa. In Sustainable hydropower in West Africa: Planning, operation, and challenges, Eds: Kabo-Bah A, Chukweumeka JD. 95-107 pp.

Gunatillake PMPC, Thiruchelvam S. 2003. An evaluation of a small scale hydropower development project in Sri Lanka: a case study in Sripadagama. Tropical Agricultural Research 15: 288-298.

Iglesias-Rios R, Mazzoni R. 2014. Measuring diversity: looking for processes that generate diversity. Natureza \& Conservação 12(2): 156-161.

Kibler KK, Tullos DD. 2013. Cumulative biophysical impact of small and large hydropower development in Nu River, China. Water Resources Research 49: 3104-3118.

Mahaweli Consultancy Bureau (Private) Limited. 2014. EIA study of the proposed north western province canal project. Asian Development Bank, Colombo.

Mendis R. 2019. Mini hydros killing many species. Ceylon Today, 18 August 2019. Available at: https://archive.ceylontoday.lk/features-more/3410. Accessed on 25/06/2020.

MOE 2012. The National Red List 2012 of Sri Lanka: conservation status of the fauna and flora. Ministry of Environment, Colombo.

Rupasinghe BWHA, De Silva SN. 2007. Environmental impacts of mini hydropower projects in Sri Lanka. Proceedings of the International Conference on Small Hydropower. Hydro Sri Lanka, Kandy, 373-382pp.

Safont E, Vegas-Vilarrúbia T, Rull V. 2012. Use of environmental impact assessment (EIA) tools to set priorities and optimize strategies in biodiversity conservation. Biological Conservation 149:113121.

SLSEA. 2017. Sri Lanka energy balance 2017: an analysis of the energy sector performance. Sri Lanka Sustainable Energy Authority, Colombo.

Silva EIL, Silva ENS. 2016. Handbook on small hydropower development and environment: a case study on Sri Lanka. Water Resources Science and Technology, Ragama.

Steinmetz M, Sundqvist N. 2014. Environmental impacts of small hydropower plants-a case study of Borås Energi och Miljö's hydropower plants. Master of Science thesis. Chalmers University of Technology, Gothenburg, Sweden.

Suratissa DM, Rathnayake US. 2016. Diversity and distribution of fauna of the Nasese Shore, Suva, Fiji Islands with reference to existing threats to the biota. Journal of Asia-Pacific Biodiversity 9(1):1116.

Thoradeniya B, Ranasinghe M, Wijesekara NTS. 2007. Social and environmental impacts of a mini hydropower project on the Ma Oya basin in Sri Lanka. Proceedings of the International Conference on Small Hydropower. Hydro Sri Lanka, Kandy, 363-372pp.

Ummalla M, Samal A. 2018. The impact of hydropower energy consumption on economic growth and $\mathrm{CO}_{2}$ emissions in China. Environmental Science and Pollution Research 25: 35725-35737.

Wijenayake T. 2016. Mini hydro-power projects and human issues. Daily News, Wednesday May 2016. Available at: http://www.dailynews.lk/2016/05/25/features/82707. Accessed on 25/06/2020.

World Commission on Dams. 2000. Dams and development: a new framework for decision-making. Earthscan Publications Ltd, London.

Zelenáková M, Fijko R, Diaconu DC, Remenáková I. 2018. Environmental impact of a small hydro power plant - a case study. Environments 5(12): 1-10. 